\title{
Early Detection of Antibodies against Various Structural Proteins of the SARS-Associated Coronavirus in SARS Patients
}

\author{
Ho-Sheng $\mathrm{Wu}^{\mathrm{a}-\mathrm{c}}$ Yueh-Chun Hsieh ${ }^{c}$ Ih-Jen Su ${ }^{b}$ Ting-Hsiang Lin ${ }^{b}$ \\ Shu-Chun Chiu ${ }^{b}$ Yu-Fen Hsu ${ }^{b}$ Jih-Hui Lin ${ }^{b}$ Mei-Ching Wang ${ }^{b}$ \\ Jeou-Yuan Chen ${ }^{d}$ Pei-Wen Hsiao ${ }^{e}$ Geen-Dong Chang ${ }^{f}$ \\ Andrew H.-J. Wang ${ }^{c}$ Hsien-Wei Ting ${ }^{c}$ Chih-Ming Choug \\ Chang-Jen Huang ${ }^{c}$
}

aGraduate Institute of Life Sciences, National Defense Medical Center, bDivision of Laboratory Research and Development, Center for Disease Control, Department of Health, Institutes of 'Biological Chemistry,

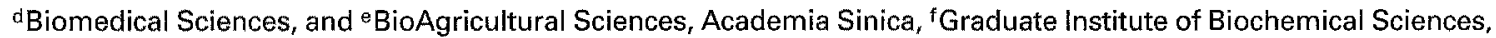
National Taiwan University, and 9Department of Biochemistry, Taipei Medical University, Taipei, Taiwan, ROC

\section{Key Words}

SARS-CoV infection - Western blotting $\cdot$ Recombinant proteins - Antibody response

\begin{abstract}
Severe acute respiratory syndrome (SARS), a new disease with symptoms similar to those of atypical pneumonia, raised a global alert in March 2003. Because of its relatively high transmissibility and mortality upon infection, probable SARS patients were quarantined and treated with special and intensive care. Therefore, instant and accurate laboratory confirmation of SARSassociated coronavirus (SARS-CoV) infection has become a worldwide interest. For this need, we purified recombinant proteins including the nucleocapsid $(N)$, envelope (E), membrane (M), and truncated forms of the spike protein (S1-S7) of SARS-CoV in Escherichia coli. The six proteins $N, E, M, S 2, S 5$, and S6 were used for Western blotting (WB) to detect various immunoglobulin classes in 90 serum samples from 54 probable SARS patients. The results indicated that $N$ was recognized in most of the sera. In some cases, $\mathbf{S 6}$ could be recognized
\end{abstract}

as early as 2 or 3 days after illness onset, while S5 was recognized at a later stage. Furthermore, the result of recombinant-protein-based WB showed a $90 \%$ agreement with that of the whole-virus-based immunofluorescence assay. Combining WB with existing RT-PCR, the laboratory confirmation for SARS-CoV infection was greatly enhanced by $24.1 \%$, from $48.1 \%$ (RT-PCR alone) to $72.2 \%$. Finally, our results show that $\lg A$ antibodies against SARS-CoV can be detected within 1 week after illness onset in a few SARS patients.

Copyright $(2004$ National Science Council, ROC and S. Karger AG, Basel

\section{Introduction}

Severe acute respiratory syndrome (SARS) is a newly emerged infectious disease. The causative agent of SARS has been identified to be a new type of coronavirus, namely SARS-associated coronavirus (SARS-CoV) [5, 8, 14]. Shortly after the 1st reported case in Guangdong, southern China, in late 2002 [2], outbreaks of SARS spread to Vietnam, Hong Kong, Singapore, Canada, and other areas, including Taiwan. As of June 30,2003, 8,447 prob-

\begin{tabular}{ll}
\hline KARGER & ( 2004 National Science Council, ROC \\
Fax +41 61.306 1234 & S. Karger AG, Basel \\
E-Mail karger@karger.ch & 1021-7770/04/0111-0117\$21.00/0 \\
www.karger.com & Accessible online at: \\
www.karger.com/jbs
\end{tabular}

Dr. Chang-Jen Huang

Institute of Biological Chemistry, Academia Sinica

No. 128 Academia Rd., Sec. 2

Taipei 115. Taiwan (ROC)

Tel. +886227855696 , Fax +886227889759 , E-Mail cjibe@gate.sinica.edu.tw 
able SARS cases including 811 deaths had been reported to the World Health Organization (WHO) from 32 countries or regions worldwide. The 1st case of SARS in Taiwan, a 54-year-old male who returned from a business trip to Guangdong, was diagnosed and reported in early March 2003 [16]. Subsequently, a large outbreak took place in late April partly due to an unrecognized SARS index patient who made multiple visits to different hospitals and exposed many patients, visitors, and health care workers [9], resulting in 678 probable cases and 84 deaths in Taiwan by the end of June [3].

The genome of the SARS-CoV is positive-sense, singlestranded RNA with sequences distantly related to all known coronaviruses that infect humans and animals [11, 15]. Like other known coronaviruses, SARS-CoV is an enveloped virus containing three envelope proteins, namely membrane $(\mathrm{M})$, envelope $(\mathrm{E})$, and spike $(\mathrm{S})$ proteins. The nucleocapsid $(\mathrm{N})$ protein, together with the viral RNA genome, presumably forms a helical core located inside the viral envelope. Based on the structure of all known coronaviruses, the $\mathrm{M}$ protein, a transmembrane glycoprotein, is the most abundant protein in the virus particle, while the $\mathrm{E}$ protein is present in a minute amount in the viral envelope. In some coronaviruses, the $S$ protein has been shown to bind to cellular receptors on the host cell surface. Generally, the immune response against the $\mathrm{S}$ protein is believed to prevent viral attachment and entry into host cells.

At the very beginning of the SARS outbreak, the case definition for SARS was merely based on clinical history and symptoms. However, after confirmation that SARS$\mathrm{CoV}$ was the causative agent, laboratory methods, including viral isolation, nucleic acid tests, and serological tests, were quickly developed and were accepted as one of the categories for a SARS diagnosis [17]. Even though the RTPCR or the real-time PCR is currently the most sensitive technique for detecting SARS-CoV, its positive rate for probable SARS cases is around 38\% according to data of the Center for Disease Control of Taiwan (CDC-Taiwan). This is likely because specimens might not be obtained at an optimal time point during the course of the SARS-CoV infection, or specimens might be taken improperly, especially for nasopharyngeal aspirates and throat swabs. Thus, it was suggested that multiple and repeated collections of nasopharyngeal, throat, and fecal samples be taken in order to increase the positive rate determined by RT-PCR. In addition to nucleic acid tests, serodiagnosis of SARS is also important. Given that SARS is a new disease in humans, antibodies against SARS-CoV should not be detected in people who have not been exposed to the virus; an antibody occurring in sera would be a useful index for SARS infection. It was reported that $\operatorname{IgG}$ against SARS-CoV was detectable in convalescent sera using SARS-CoV-infected Vero cells as antigens in an indirect immunofluorescence assay (IFA) [13].

To reduce the risk of infection, bacterially expressed recombinant SARS-CoV proteins instead of whole virus were used as antigens in the Western blotting (WB) assay. The recombinant proteins including the $\mathrm{N}, \mathrm{E}, \mathrm{M}$, and various truncated forms of the $S$ protein were tested to see whether they reacted with the sera of probable SARS patients collected during the acute and convalescent stages of the illness. Because humoral immunity displays different isotypes of antibodies, including $\operatorname{IgA}, \operatorname{IgG}$, and $\operatorname{IgM}$, during the infection, we thus evaluated whether these antibodies could be used as diagnostic indices for SARS infection. The results of WB analyses were summarized and compared with those of IFA and RT-PCR. Overall, the results between the recombinant protein-based $\mathrm{WB}$ and whole-virus-based IFA showed a high correlation.

\section{Materials and Methods}

\section{Construction of Expression Plasmids}

The coding regions for the SARS-CoV proteins $\mathrm{N}, \mathrm{M}$, and $\mathrm{E}$ and fragments of S (S1, S2, S3, S4, S5, S6, and S7) protein were amplified by 30 cycles of PCR using reverse-transcribed RNA extracted from the Urbani strain of SARS-CoV (GenBank accession No. AY278741). The Urbani strain with 29,727 nucleotides in length was kindly provided by the Centers for Disease Control and Prevention (CDC-US; Atlanta, Ga., USA). Sequences of the primers used in the PCR are listed in table 1, the amplicons from which carried either BamHI/Sall or BamHI/HindIII restriction sites. The size of the nucleotide sequence of $\mathrm{N}$ was $1,269 \mathrm{bp}$, those of $\mathrm{M} 666, \mathrm{E} 231, \mathrm{~S} 1$ $429, \mathrm{~S} 2353, \mathrm{~S} 3560, \mathrm{~S} 4725, \mathrm{~S} 5630, \mathrm{~S} 6690$, and S7 663 bp. The amplified products were purified from the gel and cloned into the pQE30 expression vector (Qiagen, Studio City, Calif., USA). The resulting constructs were transformed into Escherichia coli JMI09 cells (Invitrogen, Carlsbad, Calif., USA). All sequences of inserts were verified using an ABI 3730 DNA analyzer (Applied Biosystems, Tokyo, Japan).

\section{Expression and Purification of Recombinant Proteins}

These proteins were expressed in $E$. coli JM109. A colony of $E$. coli cells was separately inoculated into LB broth in the presence of $100 \mu \mathrm{g} / \mathrm{ml}$ ampicillin, and the culture was grown overnight at $37^{\circ} \mathrm{C}$, until its optical density reached 1.2 at $600 \mathrm{~nm}$. To induce expression of these recombinant proteins, isopropyl- $\beta$ - $D$-thiogalactopyranoside (IPTG) was added to a final concentration of $1.0 \mathrm{mM}$, and the incubation was continued for $4 \mathrm{~h}$. All recombinant proteins accumulated in the bacteria as inclusion bodies. The cells were harvested by centrifugation and used for the preparation of inclusion bodies. Briefly, cells from $5 \mathrm{ml}$ of culture were resuspended in $1 \mathrm{ml}$ of phosphate-

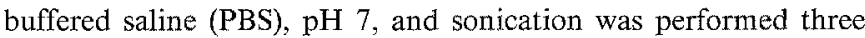
times in an ice bath at 10-second intervals to disrupt the cells. After 
Table 1. Primers used for amplification of various DNA fragments of SARS-CoV

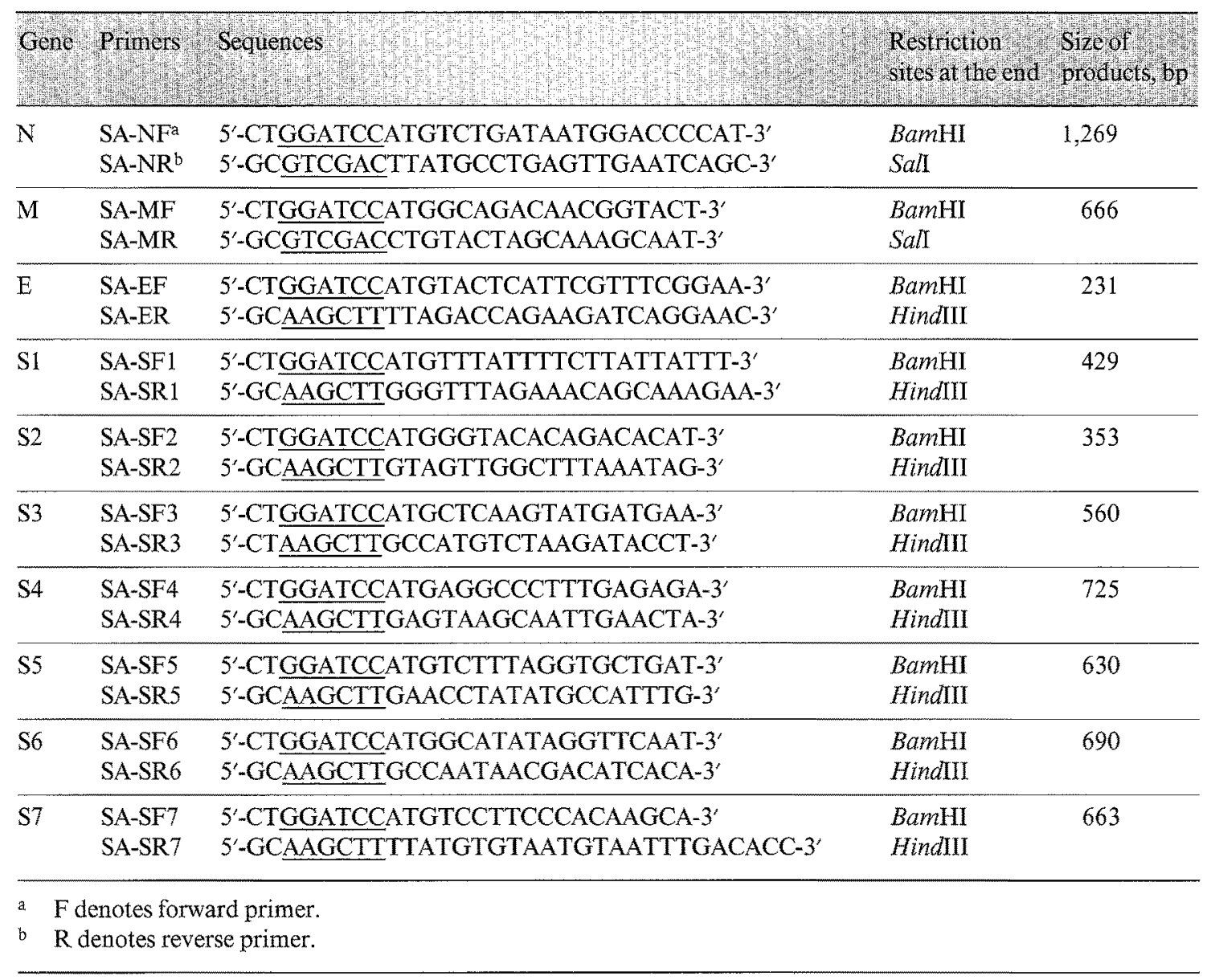

centrifugation at $13,000 \mathrm{rpm}$ for $5 \mathrm{~min}$, the pellet was resuspended in an Eppendorf vial containing 1.5\% sarcosine and $10 \mathrm{~m} M$ Tris- $\mathrm{HCl}$ buffer, $\mathrm{pH} 7.0$, vortexed at room temperature for $1 \mathrm{~h}$, until the lysate appeared clear, and recentrifuged at $13,000 \mathrm{rpm}$ for $5 \mathrm{~min}$. The supernatant was collected, and BD TALONTM metal affinity resins (BD Biosciences, San Jose, Calif., USA) were then added. The vials were mildly agitated at $4{ }^{\circ} \mathrm{C}$ overnight. The resins were centrifuged and washed twice with $10 \mathrm{mM}$ Tris $\mathrm{HCl}$ buffer containing $1 \mathrm{MNaCl}$. These proteins were examined by $12 \%$ SDS-PAGE. The proteins were either stained with Coomassie blue or were transferred to a polyvinylidene difluoride membrane (PVDF Immobilon $P$, pore size $0.45 \mu \mathrm{m}$; Millipore, Bedford, Mass., USA) to determine the recombinant proteins. To eliminate the few bacterial contaminants present in the inclusion bodies, these recombinant proteins were eluted with 50-200 $\mathrm{m} M$ imidazole solution according to the manufacturer's instructions.

\section{Human Sera}

According to WHO criteria, a person presenting after November 1,2002 , with a history of high fever $\left(>38^{\circ} \mathrm{C}\right)$, coughing, or breathing difficulty and having resided in or traveled to an area with recent local transmission of SARS during the 10 days prior to onset of symptoms was classified as a suspected case. A suspect case with radio- graphic evidence of infiltrates consistent with pneumonia or respiratory distress syndrome on a chest X-ray was considered a probable case. In this study, 90 human serum samples from 54 patients, fulfilling WHO criteria for probable SARS cases, were selected from hospitalized patients in northern Taiwan. Of these 18 male and 38 female cases, 36 had paired sera, and 18 had only single serum collected either at the acute stage or in the convalescent stage of the illness. All serum samples had been analyzed for SARS-CoV by RT-PCR, among which 48 were positive and 42 negative. The primers used for the RT-PCR were synthesized according to CDC-US recommendations [8]. The handling of specimens, such as collecting, taking aliquots of, or diluting specimens, and the practice of nucleic acid extraction or the RT-PCR assay were performed in BSL-2 (biosafety level 2) laboratories. Laboratory workers were required to wear protective equipment, including disposable gloves, laboratory coats, and an $\mathrm{N}-95$ mask.

Horseradish Peroxidase (HRP) Conjugated Antihuman IgA, IgG and IgM

HRP-conjugated goat antihuman immunoglobulins, IgA ( $\alpha$ chain), IgG ( $\gamma$ chain), and IgM ( $\mu$ chain), were purchased from Savyon Diagnostics (Ashdod, Israel). These products were purified with affinity columns. 


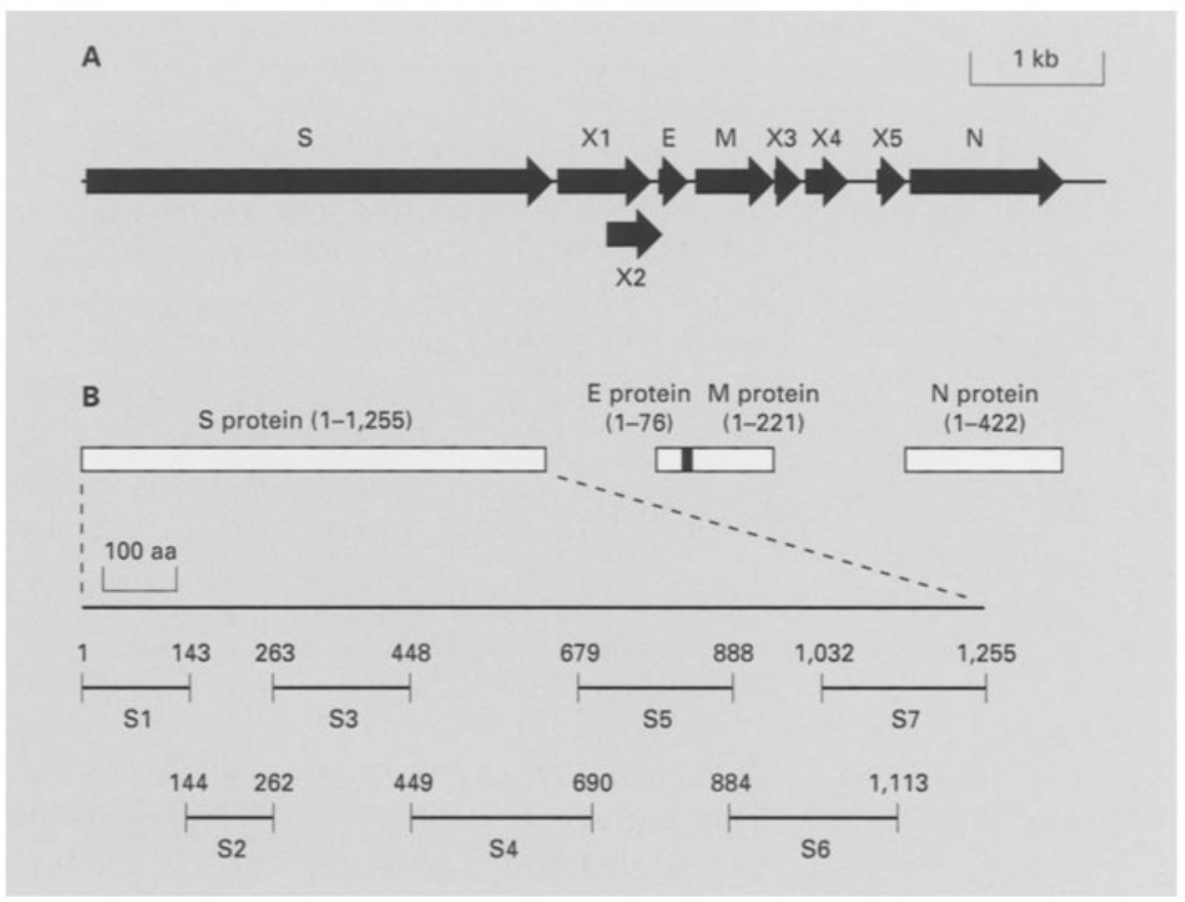

Fig. 1. Partial genomic structure of SARSCoV. A Localization of known genes encoding the proteins $\mathrm{S}$ (spike glycoprotein), $\mathrm{E}$ (small-envelope protein), $M$ (membrane glycoprotein), and $N$ (nucleocapsid) and other putative open reading frames, X1-X5. B The $\mathrm{S}, \mathrm{E}, \mathrm{M}$, and $\mathrm{N}$ proteins contained $1,255,76$, 221, and 422 amino acid residues, respectively. Seven consecutive truncated forms of $\mathrm{S}$ protein, designated $\mathrm{S} 1-\mathrm{S} 7$, are indicated with an enlarged scale.

\section{Immunofluorescence Assay}

Vero E6 cells were grown in MEM containing $10 \%$ fetal bovine serum at $35^{\circ} \mathrm{C}$. At a density of $80 \%$, the cells were infected with SARS-CoV $\left(10^{6} / \mathrm{ml}\right)$. After cytopathic effects appeared, the cells were washed with $0.025 \%$ trypsin and spotted onto slides. These slides were placed in a closed heating container, until they completely dried, then the slides were fixed in acetone for $15 \mathrm{~min}$. Ten microliters of diluted serum, starting from 1:100, was placed onto each well of the slide and incubated at $37^{\circ} \mathrm{C}$ for $30 \mathrm{~min}$. After washing twice with PBS for 5 min each, $10 \mu$ of 1:100-diluted specific antihuman gamma globulins labeled with FITC (Zymed Laboratories, South San Francisco, Calif., USA) was added to each well and incubated at $37^{\circ} \mathrm{C}$ for $30 \mathrm{~min}$. After washing twice with PBS, the slides were observed under a fluorescence microscope. Culture of the virus and preparation of viral antigens for IFA were conducted in a BSL-3 laboratory. After being fixed with acetone, the IFA slides were examined in a BSL-2 laboratory.

\section{Western Blotting}

Equal amounts of purified recombinant proteins were mixed, subjected to SDS-PAGE, and transferred to PVDF membranes. The membranes were blocked with $5 \%$ skim milk (Difco, Sparks, Md., USA) in PBS for $2 \mathrm{~h}$ at room temperature and then were sliced into strips $(0.5 \times 8 \mathrm{~cm})$. Therefore, the loading in each strip was theoretically equal. Serum samples were 1:500 diluted with 5\% skim milk. Two milliliters of the diluted serum was added to each strip and incubated overnight at $4^{\circ} \mathrm{C}$. On the following day, these strips were washed with PBS containing $0.2 \%$ Tween 20 three times for $10 \mathrm{~min}$ each and incubated at room temperature for $2 \mathrm{~h}$ with $2 \mathrm{ml}$ of $1: 1,000-$ diluted goat antihuman IgG, IgA, and IgM HRP conjugate (Savyon Diagnostics) separately. After washing as described above, the strips were incubated in ECL solution (Perkin-Elmer Life Sciences, Boston,
Mass., USA) for $1 \mathrm{~min}$. The strips were then dried and exposed to $X$-ray film to visualize the reaction.

\section{Statistics}

Sensitivity [number of true positives/(number of true positives + number of false negatives)] and specificity [number of true negatives/ (number of true negatives + number of false positives)] were calculated as previously described [1]. The antibody response of different immunoglobulin classes to SARS-CoV recombinant proteins was plotted according to the optical density of the WBs which were scanned and quantified using Totallab software (Nonlinear Dynamics, Newcastle upon Tyne, UK). The value of each band was normalized with the control serum. Results were subjected to Sigma Plot for curve plotting and pair-to-pair t-test. For all statistical analyses $\mathrm{p}<$ 0.05 was considered significant.

\section{Results}

\section{Expression and Purification of Recombinant SARS-CoV Proteins}

The encoding regions for the full-length $\mathrm{E}, \mathrm{M}$, and $\mathrm{N}$ proteins and the truncated forms of S proteins of SARS$\mathrm{CoV}$ are marked in figure 1. For easy handling, the 1,255 amino acid long open reading frame of the $S$ protein was split into seven consecutive truncated forms of polypeptides, designated S1-S7. After induction with IPTG, most of the proteins were synthesized and were present in inclusion bodies. They were resolved in buffer containing 
$1.5 \%$ sarcosine and were purified by metal affinity resins. Samples of the bacterially expressed SARS-CoV N, M, E, $\mathrm{S} 2, \mathrm{~S} 5$, and $\mathrm{S} 6$ proteins were analyzed and are shown in figure 2. The molecular masses of N, E, S2, S5, and S6 were $46,10,14,23$, and $25 \mathrm{kD}$, respectively, as expected. However, the apparent molecular mass of recombinant $M$ protein in gel, at $35 \mathrm{kD}$, was larger than the calculated size (approximately $25 \mathrm{kD}$ ), possibly due to the high content of hydrophobic amino acid residues $(49 \%, 109 / 221)$ in the $\mathrm{M}$ protein. The recombinant proteins of $\mathrm{S} 1, \mathrm{~S} 3, \mathrm{~S} 4$, and $\mathrm{S} 7$ were poorly expressed in $E$. coli; therefore, they were not used in the study (data not shown).

WB Analysis for Detection of Antibodies to SARS-CoV

The recombinant proteins were then pooled and tested to see whether they reacted with the antibodies in the serum samples of probable SARS patients by WB analysis. Among them, 14 positive results in our WB and RTPCR analyses, which also represent various stages of the illness, were selected and are presented in figure 3. Serum samples of these patients were collected from the 2 nd through the 33rd days after the onset of illness and were labeled F-1854-D2, for example, to indicate female patient 1854's day 2 serum. Two serum samples from healthy people were used as negative controls for SARSCoV-specific antibodies (fig. 3, lanes 1 and 16). As shown in figure 3 , the $\mathrm{N}$ protein could be recognized by $\operatorname{IgA}, \operatorname{IgG}$, or IgM (fig. 3A, lanes 4-15; fig. 3B, lanes 8-11, 13-16; fig. 3C, lanes 7, 8, 13-15). However, the S (S5 or S6) and $\mathrm{M}$ proteins were recognized by $\operatorname{IgA}$ or IgG, but were barely recognized by IgM (fig. 3A, lanes 2, 3, 11-15; fig. 3B, lanes 3-5, 8-15; fig. 3C, lanes 5, 7, 11). Two recombinant proteins, $E$ and $S 2$, were not recognized by $\operatorname{IgA}, \operatorname{IgG}$, or IgM in any serum of SARS patients. A protein band with an arrowhead might represent degraded products of $M$ protein or contaminated unknown proteins copurified with the recombinant $M$ protein. Since a specific IgM was found to weakly react with $M$ and $S$ antigens and since positive cases for $\operatorname{IgM}$ were all included in that of $\operatorname{IgA}$ or $\mathrm{IgG}, \mathrm{IgM}$ was not further analyzed in the following studies. Taken together, our results demonstrated that recombinant N, M, S5, and S6 proteins could be used as diagnostic markers for SARS-CoV infection.

\section{Response Profile of Various Immunoglobulins to}

Recombinant Proteins

In order to elucidate more clearly the antibody response to various antigens of SARS-CoV, line diagrams were drawn according to the WB results (fig. 3) by Sigma Plot version 8.0 and were normalized with the data of 2

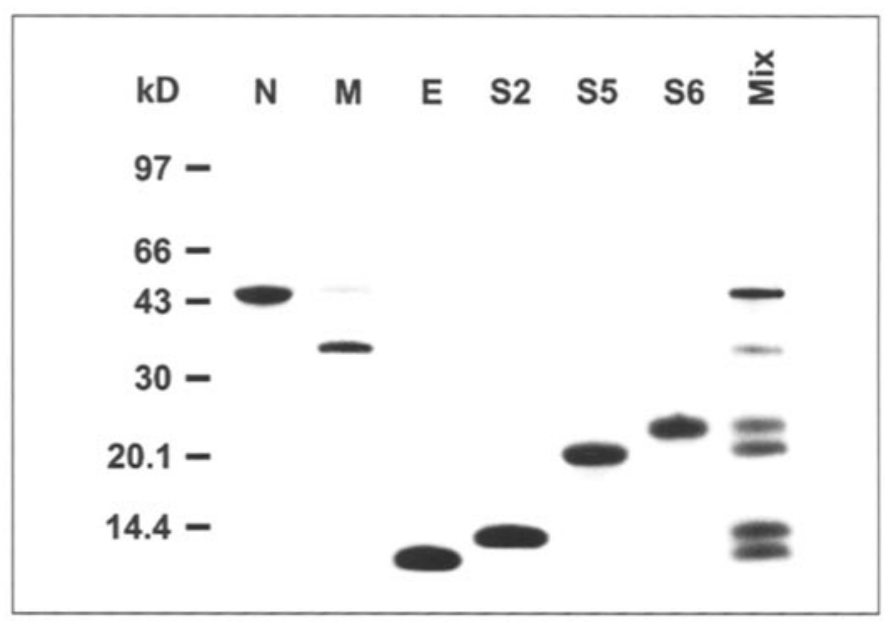

Fig. 2. Recombinant proteins $\mathrm{N}, \mathrm{M}, \mathrm{E}, \mathrm{S} 2, \mathrm{~S} 5$, and $\mathrm{S} 6$ produced in $E$ coli. The proteins were purified with affinity resins and stained with Coomassie blue after SDS-PAGE on a $12 \%$ polyacrylamide gel. Lanes 1-6 show individual purified proteins. Lane 7 shows the six pooled proteins used for WB analysis.

healthy volunteers. However, it must be emphasized that this antibody response profile represents pooled data selected from 14 probable SARS patients, not the kinetic change of 1 individual. As shown in figure $4, N$ protein possessed major antigenicity to various antibodies (IgA, IgG, and IgM). Noticeably, the antibody response of IgA to $\mathrm{N}$ protein was initiated as early as day 2 or 3 after illness onset, with a sevenfold increase which progressively increased to 15 -fold within 1 month (fig. 4A). The increased multiples of antibodies to $\mathrm{N}$ protein were significantly higher than those of $\mathrm{M}$ proteins and $\mathrm{S}$ proteins according to the paired t-test $(\mathrm{p}<0.01$ and $\mathrm{p}<0.05$, respectively). The responses of IgM and IgG to $\mathrm{N}$ protein were similar to that of IgA. However, they appeared on days 10 and 16, respectively, after the onset of illness. The $\mathrm{M}$ protein could be detected by IgA or IgG. The antibody response to $\mathrm{M}$ protein was much lower than that to $\mathrm{N}$ protein (fig. 4A-C). Interestingly, few patients had an IgA antibody response to spike proteins in the early stage (days 2-3), but most other patients had a similar response in the convalescent stage (days 16-21 after illness onset).

\section{Relative Sensitivity and Specificity of $\operatorname{IgA}$ and $\operatorname{Ig} G$ Responses to SARS-CoV Infection}

Table 2 summarizes the results of the 48 RT-PCR-positive serum samples of probable SARS cases by WB, in which $\mathrm{N}$-related antigens $(\mathrm{N}, \mathrm{N}+\mathrm{M}, \mathrm{N}+\mathrm{M}+\mathrm{S}$, and $\mathrm{N}+$ S) showed a positive rate of $54.2 \%$ ( 26 of 48$)$ for detection 


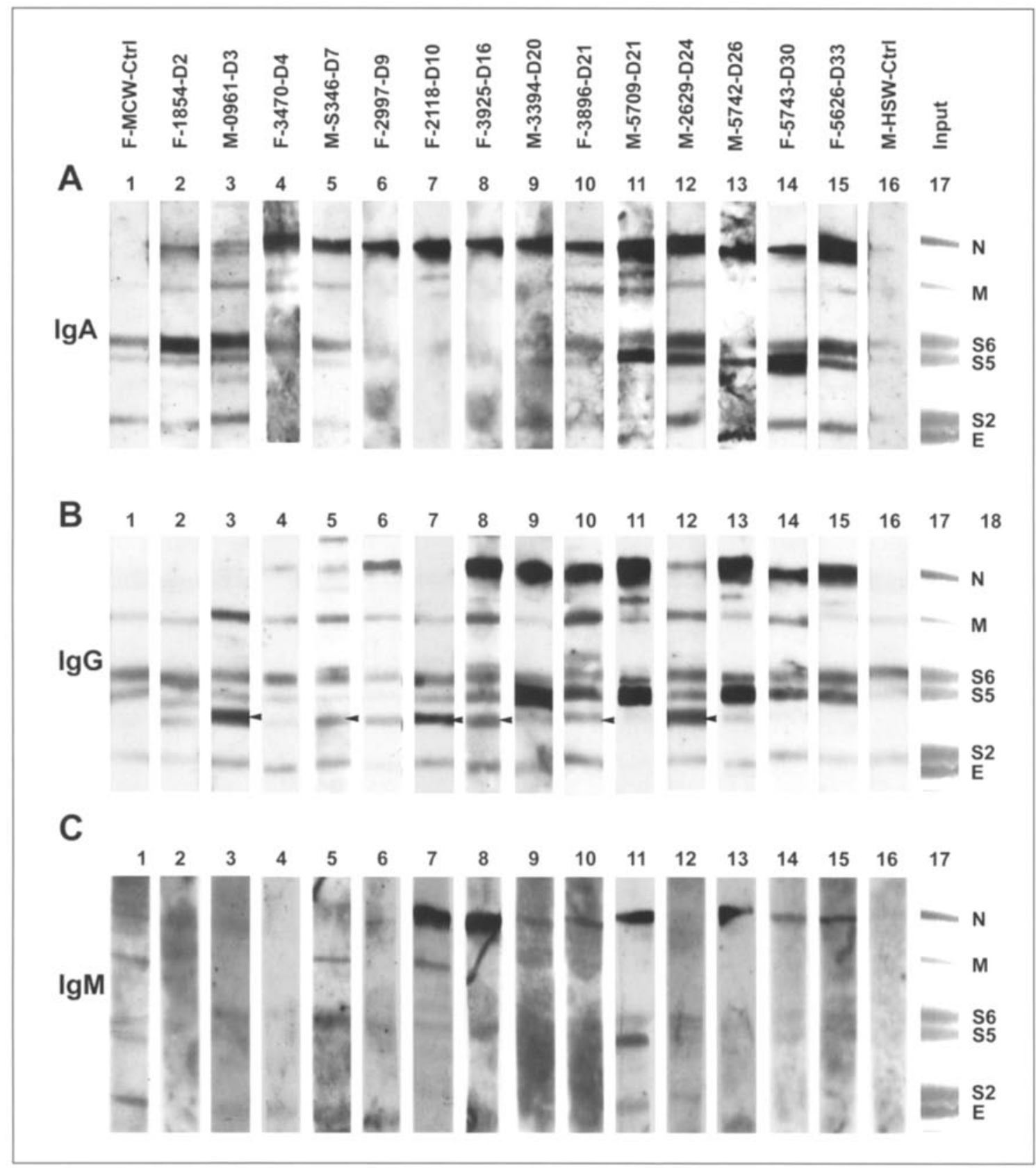

Fig. 3. Detection of various subclasses of immunoglobulins against SARS-CoV in sera from 14 probable SARS cases and 2 normal volunteers by WB analysis. The serum sample from each SARS patient was labeled F-1854-D2 (lane 2), for example, to indicate that the serum was collected from female patient 1854 on day 2 after ilness onset. Similarly, F-MCW-Ctrl (lane 1) demonstrated that the serum was collected from healthy female MCW. The input antigens were either stained with a $0.2 \%$ amido black solution (lane 17) or used to detect various subclasses of immunoglobulins, such as $\operatorname{IgA}(\mathbf{A}), \operatorname{IgG}(\mathbf{B})$, and $\operatorname{IgM}(\mathbf{C})$, in the sera of SARS patients (lanes 2-15). 
Fig. 4. Response profile of various immunoglobulins to recombinant proteins. Following SARS-CoV infection, antibodies against proteins $\mathrm{N}$ (solid line), S (dash-dot-dot line), and $M$ (dash line) were gradually produced. A IgA expression profile. The antibody response to $\mathrm{N}$ protein was higher than those to $\mathrm{M}$ and $\mathrm{S}$ proteins $(\mathrm{p}<0.01$ and $\mathrm{p}<0.05$, respectively, by paired t test). B IgG expression profile. The antibody response to $\mathrm{N}$ protein was higher than those to $M$ and $S$ proteins ( $p<0.05$ by paired $t$ test). C $\operatorname{IgM}$ expression profile. The antibody response to $\mathrm{N}$ protein did not significantly differ from those of $\mathrm{M}$ and $\mathrm{S}$ proteins ( $\mathrm{p}>0.1$ by paired t-test).

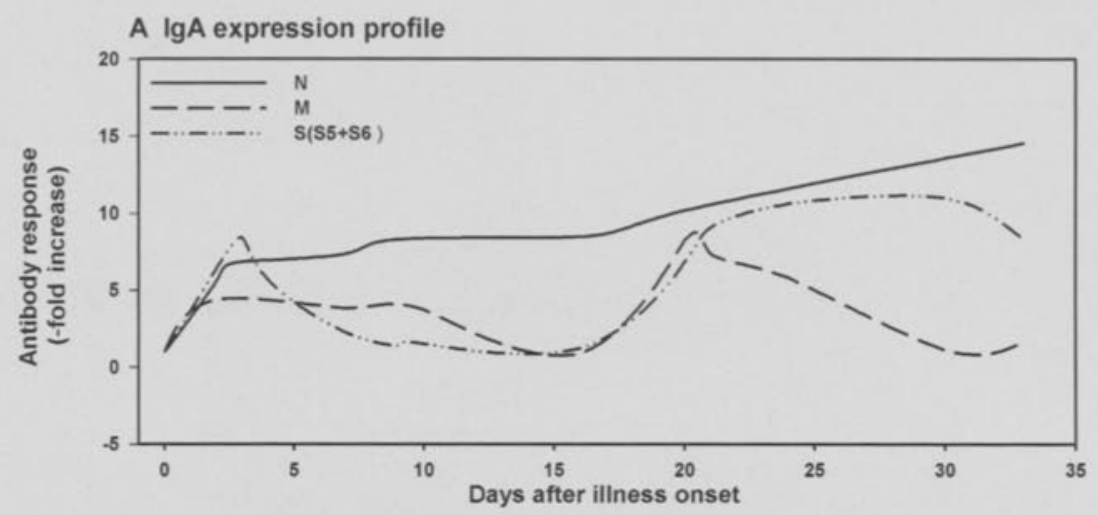

B IgG expression profile

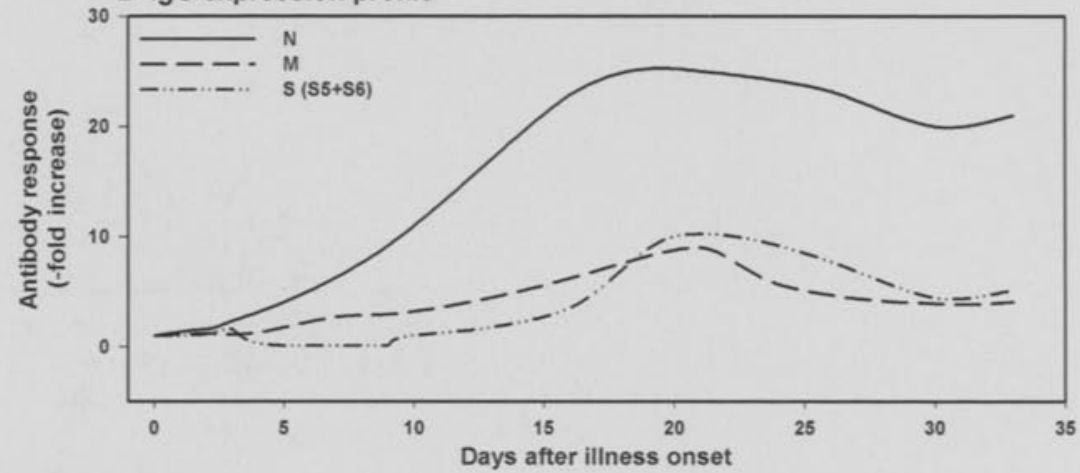

C IgM expression profile

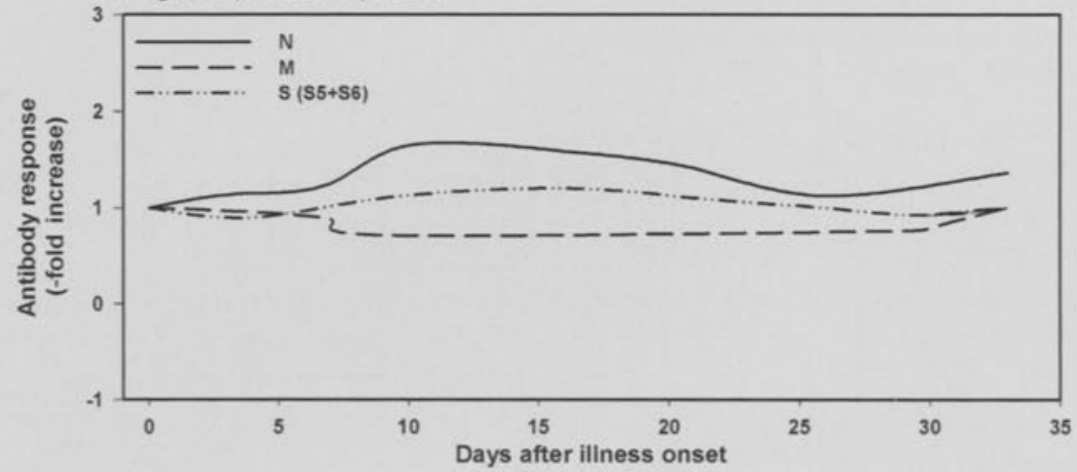

of specific IgA antibodies and 39.6\% (19 of 48) for IgG. If the results of $\operatorname{IgA}$ and $\operatorname{IgG}$ were combined, the positive rate was increased to $58.3 \%$ ( 28 of 48 ). As to $\mathrm{S}$ antigens (S5, S6, S5 + S6), 14.6\% (7 of 48) patients were positive for the IgA response and 8.3\% (4 of 48 ) for IgG. The positive rate was not increased, even if estimated using both IgA and IgG together, because the positive number for IgG was included in that of IgA. Taking the pooled antigens of $N, M, S 5$, and $S 6$ together, the positive rate for detection of antibodies was $68.8 \%(33 / 48)$ for $\operatorname{IgA}, 47.9 \%$ (23/48) for IgG, and $72.9 \%$ (35/48) for IgA or IgG.

\section{Comparison of Recombinant-Based WB with \\ Whole-Virus-Based IFA}

To evaluate the sensitivity and specificity of the WB assay using the recombinant proteins in this study, we compared data from WB with the results of whole-virusbased IFA. Table 3 shows sensitivity and specificity of 
Table 2. Antibody responses to different viral antigens in 48 positive RT-PCR sera by WB
Table 3. Comparison of recombinant protein-based WB with whole-virus-based IFA for SARS-COV

\begin{tabular}{|c|c|c|c|c|c|c|}
\hline \multirow{3}{*}{ Viral antigens } & \multicolumn{6}{|c|}{ Isotypic anti-SARS CoV antibodies } \\
\hline & \multicolumn{2}{|c|}{ IgA positive } & \multicolumn{2}{|c|}{ IgG positive } & \multicolumn{2}{|c|}{ IgA or IgG positive } \\
\hline & $\mathrm{n}$ & $\%$ & $\mathrm{n}$ & 06 & n & $\%$ \\
\hline \multirow{3}{*}{$\begin{array}{l}\mathrm{N} \\
\mathrm{N}+\mathrm{M} \\
\mathrm{N}+\mathrm{M}+\mathrm{S} 6\end{array}$} & 10 & 22.9 & 6 & 12.5 & & \\
\hline & 3 & 6.3 & 5 & 10.4 & & \\
\hline & 3 & 6.3 & 1 & 2.1 & & \\
\hline \multirow{3}{*}{$\begin{array}{l}\mathrm{N}+\mathrm{S} 5 \\
\mathrm{~N}+\mathrm{S} 6 \\
\mathrm{~N}+\mathrm{S} 5+\mathrm{S} 6\end{array}$} & 4 & 8.3 & 4 & 8.3 & & \\
\hline & 3 & 8.3 & 2 & 4.2 & & \\
\hline & 3 & 6.3 & 0 & 0 & & \\
\hline N related & 26 & 54.2 & 18 & 37.5 & 27 & 56.3 \\
\hline$M$ & 0 & 0 & 1 & 2.1 & 1 & 2.1 \\
\hline S5 & 2 & 4.2 & 3 & 6.3 & & \\
\hline S6 & 3 & 6.3 & 0 & 0 & & \\
\hline $\mathrm{S} 5+\mathrm{S} 6$ & 2 & 4.2 & 1 & 2.1 & & \\
\hline$S^{b}$ & 7 & 14.6 & 4 & 8.3 & 7 & 14.6 \\
\hline$N$ related $^{a}+\mathrm{M}+\mathrm{S}^{b}$ & 33 & 68.8 & 23 & 47.9 & 35 & 72.9 \\
\hline Total specimens & \multicolumn{6}{|l|}{48} \\
\hline \multicolumn{7}{|c|}{$\begin{array}{l}\text { a related represents the total number of } \mathrm{N}, \mathrm{N}+\mathrm{M}, \mathrm{N}+\mathrm{M}+\mathrm{S} 6, \mathrm{~N}+\mathrm{S} 5, \mathrm{~N}+\mathrm{S} 6, \mathrm{~N}+\mathrm{S} 5+\mathrm{S} 6 \text {. } \\
\mathrm{S} \text { represents the total number of } \mathrm{S} 5, \mathrm{~S} 6 \text {, and } \mathrm{S} 5+\mathrm{S} 6 \text {. }\end{array}$} \\
\hline
\end{tabular}

\begin{tabular}{|c|c|c|c|c|c|c|}
\hline \multirow{2}{*}{$\mathrm{WB}$} & \multicolumn{2}{|c|}{ Sensitivity } & \multicolumn{2}{|c|}{ Specificity } & \multicolumn{2}{|c|}{ Overall agreement } \\
\hline & 0 & $\mathrm{n}$ & $\%$ & a & $\%$ & $\mathrm{n}$ \\
\hline IgA & 89.1 & $41 / 46$ & 88.6 & $39 / 44$ & 88.9 & $80 / 90$ \\
\hline $\operatorname{Ig} G$ & 73.9 & $34 / 46$ & 97.7 & $43 / 44$ & 85.6 & $77 / 90$ \\
\hline $\operatorname{Ig} A$ or $\operatorname{IgG}$ & 91.3 & $42 / 46$ & 88.6 & $39 / 44$ & 90.0 & $81 / 90$ \\
\hline
\end{tabular}

a Number of true positives divided by total number of IFA-positive sera.

- Number of true negatives divided by total number of IFA-negative sera.

- Sum of the number of true positives and true negatives divided by total serum samples.
WB as compared with IFA, in which the measurement of IgA antibodies had a sensitivity of $89.1 \%$ and a specificity of $88.6 \%$; for IgG antibodies, sensitivity and specificity were 73.9 and $97.7 \%$, and for IgA or IgG antibodies, they were 91.3 and $88.6 \%$, respectively. The overall agreement of WB with IFA was $90.0 \%$ ( 81 of 90$)$.

Laboratory Confirmation Rate with RT-PCR and WB Table 4 shows the results of RT-PCR and WB in the acute and convalescent stages of the illness in 54 probable SARS patients. Throat swab specimens were used for RTPCR, and cognate serum samples were used for the WB assay. In the single-serum group, the positive rates of RTPCR and WB were measured at 50\% (4/8) and 25\%(2/8) for specimens collected in the acute stage (days 1-12 after illness onset), and the positive rates for RT-PCR and WB were $40 \%(4 / 10)$ and $60 \%(6 / 10)$, respectively, in the convalescent stage (days 19-41 after illness onset). In the paired-sera group, the positive rates of RT-PCR and WB were $50 \%(18 / 36)$ and $75 \%(27 / 36)$, respectively. Overall, the positive rate was $48.1 \%(26 / 54)$ for RT-PCR and $64.8 \%(35 / 54)$ for WB. Combining RT-PCR and WB results, the laboratory confirmation rate for probable SARS patients increased to $72.2 \%(39 / 54)$. 
Table 4. Laboratory-confirmed rate with RT-PCR and WB in probable SARS cases

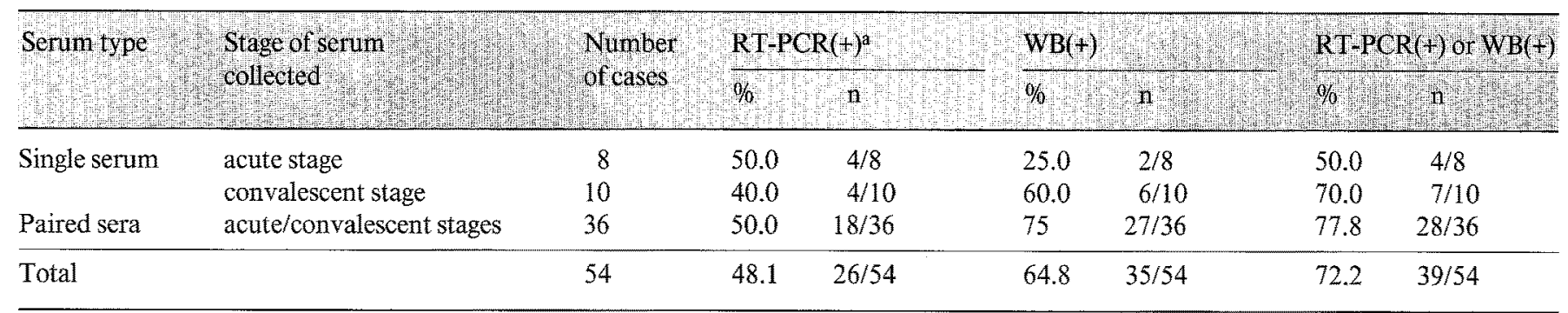

a Throat swabs were used for the RT-PCR assay.

\section{Discussion}

A WB assay using recombinant proteins as antigens was developed to detect SARS-CoV-specific antibodies. To evaluate whether the WB could be used, sensitivities and specificities were measured and compared with those of IFA. As shown in table 4, the recombinant-proteinbased WB analysis correlated very well with the wholevirus-based IFA. These findings indicate that the recombinant proteins of N, M, S5, and S6 may be useful as antigens to detect specific antibodies against SARS-CoV. Moreover, large amounts of recombinant proteins can easily be obtained in an $E$. coli system which offer several advantages over the antigens prepared from virus-infected cells, such as decreasing the risk of infection and ease of performing the assay with standardization.

As shown in table 2, N-related antigens showed a principal antigenicity of $58.3 \%$ for SARS-CoV in RT-PCRpositive patients, and $\mathrm{S}$ antigens contributed $14.6 \%$ to the overall positive rate of $72.9 \%$. These data are related to those of Krokhin et al. [7] who conducted a WB assay using convalescent sera of SARS patients to detect proteins in the supernatants of cells containing SARS-CoV and identified the predominant protein $\mathrm{N}$ and minute quantities of protein S. However, we could not detect antibodies against $E$ protein, and only a few SARS patients $(19.2 \%, 10 / 54)$ had antibodies against M protein. These findings are not correlated with the results obtained by Elia et al. [6] who reported that antibodies against $M$ protein of a canine coronavirus were consistently detected in seropositive dogs.

In terms of the reactivity of different immunoglobulin classes, we found that specific IgA antibodies already existed 2 or 3 days after illness onset in some cases; however, at the same time, IgM antibodies could not be detected in the same patients (fig. 3). The weak signal of
IgM might have resulted from the characteristics of IgM itself, since the affinity of $\operatorname{IgM}$ to antigens is relatively low as compared with that of $\operatorname{IgG}$ or $\operatorname{IgA}$. Therefore, the detectable sensitivity of IgM to SARS-CoV proteins is limited. The human respiratory tract has been proposed to be the major site of SARS-CoV infection in humans, and it is totally covered with mucosal surfaces. Not only do cellular immune responses result from mucosal infection by intracellular pathogens, but also secretory IgAs are produced to function as another important defense mechanism against invasion of deeper tissues by these pathogens [18]. Therefore, the synthesis of specific IgA antibodies in the early stage of a SARS-CoV infection is reasonable, and this phenomenon was also observed in other studies related to coronaviruses $[4,10,12]$. For example, Loa et al. [10] reported that the specific IgA antibodies against a turkey coronavirus were initially detected in serum 1 week after oral inoculation; these gradually increased and reached a peak at week 4 and finally declined at weeks $6-9$. Furthermore, we noted that all three classes of immunoglobulins reacted with $\mathrm{N}$ and $\mathrm{S}$ antigens, but the antibody response of IgM to $\mathrm{S}$ antigen was much lower than that of IgA or IgG. Whether this phenomenon is significant for the immunological role of IgA, IgG, or IgM in SARS patients requires more detailed investigation.

Table 4 illustrates that RT-PCR was more sensitive than WB during the acute phase of SARS-CoV infection. However, WB was more sensitive than RT-PCR, if sera were collected in the convalescent phase of the illness. In general, the combined use of RT-PCR and WB raised the positive rate from 48.1 to $72.2 \%$ for probable SARS patients. Taken together, our data indicate that the use of recombinant protein-based WB along with RT-PCR can increase the rate of confirmation of suspected SARS patients. 
Although most of the antibodies to $\mathrm{S}(\mathrm{S} 5$ or $\mathrm{S} 6$ ) protein were detected during the later stage of the disease, 2 of 44 serum samples collected during the acute phase had antibodies against S6 on days 2 and 3 after illness onset (fig. 4). Since the data were pooled from many patients, we do not know whether this pattern was truly significant or merely due to variations among different individuals. Nonetheless, it is still valuable to elucidate the trend of antibody responses in different classes of immunoglobulins against various SARS-CoV antigens during the course of the infection.

In summary, our data suggest that WB using recombinant proteins $N, \mathrm{M}, \mathrm{S} 5$, and $\mathrm{S} 6$ as antigens to detect various classes of immunoglobulins might provide an alter- native method for the early detection of SARS-CoV infection. In addition, detection of specific IgA antibodies at the very early stage of the illness may be valuable for monoclonal antibodies or vaccine development to combat the SARS-CoV infection.

\section{Acknowledgements}

We thank Dr. Jyh-Yuan Yang for providing the Urbani strain of the SARS-CoV RNA, Dr. Shu-Ying Li for providing the specific goat antihuman $\operatorname{IgG}, \operatorname{IgA}$, and IgM HRP conjugate, and all members of the SARS Laboratory Diagnostic Team of CDC-Taiwan for their excellent performance during the SARS outbreak in Taiwan.

\section{References}

1 Bittner J. Evaluation of the diagnostic value of laboratory investigations. J Clin Chem Clin Biochem 15:1-12;1977.

2 CDC SARS Investigative Team, Fleischauer AT, Outbreak of severe acute respiratory syndrome - worldwide, 2003. Mor Mortal Wkly Rep 52:226-228;2003.

3 Cumulative number of SARS probable cases in Taiwan, SARS Online Information Center, Center for Disease Control, Taiwan [Accessed July 2, 2003]. Available from: URL: http:/ /www.cdc.gov.tw/sarsen.

4 de Arriba ML, Carvajal A, Pozo J, Rubio P. Mucosal and systemic isotype-specific antibody responses and protection in conventional pigs exposed to virulent or attenuated porcine epidemic diarrhoea virus. Vet Immunol Immunopathol 85:85-97;2002.

5 Drosten C, Gunther S, Preiser W, van der Werf $S$, Brodt HR, Becker S, Rabenau H, Panning M, Kolesnikova L, Fouchier RA, et al. Identification of a novel coronavirus in patients with severe acute respiratory syndrome. N Engl $\mathbf{J}$ Med 348:1967-1976;2003.

6 Elia $G$, Fiermonte $G$, Pratelli A, Martella $V$, Camero M, Cirone F, Buonavoglia C. Recombinant $M$ protein-based ELISA test for detection of antibodies to canine coronavirus. $J$ Virol Methods 109:139-142;2003.
7 Krokhin O, Li Y, Andonov A, Feldman H, Flick R, Jones S, Stroeher U, Bastien N, Dasuri $\mathrm{KV}$, Cheng $\mathrm{K}$, et al. Mass spectrometric characterization of proteins from the SARS virus: A preliminary report. Mol Cell Proteomics 2: 346-356;2003.

8 Ksiazek TG, Erdman D, Goldsmith CS, Zaki SR, Peret T, Emery S, Tong S, Urbani C, Comer JA, Lim W, et al. A novel coronavirus associated with severe acute respiratory syndrome. N Engl J Med 348:1953-966;2003.

9 Lee ML, Chen CJ, Su IJ, Chen KT, Yeh CC, King CC, Chang HL, Wu YC, Ho MS, Jiang $\mathrm{DD}$, et al. Severe acute respiratory syndrome Taiwan, 2003. Morb Mortal Wkly Rep 52:461$466 ; 2003$.

10 Loa CC, Lin TL, Wu CC, Bryan T, Hooper T, Schrader D. Specific mucosal IgA immunity in turkey poults infected with turkey coronavirus. Vet Immunol Immunopathol 88:57-64;2002.

11 Marra MA, Jones SJ, Astell CR, Holt RA, Brooks-Wilson A, Butterfield YS, Khattra J, Asano JK, Barber SA, Chan SY, et al. The Genome sequence of the SARS-associated coronavirus. Science 300:1399-1404;2003.

12 Naslund K, Traven M, Larsson B, Silvan A, Linde N. Capture ELISA systems for the detection of bovine coronavirus-specific IgA and IgM antibodies in milk and serum. Vet Microbiol 72:183-206;2002.
13 Peiris JS, Chu CM, Cheng VC, Chan KS, Hung IF, Poon LL, Law KI, Tang BS, Hon TY, Chan $\mathrm{CS}$, et al. Clinical progression and viral load in a community outbreak of coronavirus-associated SARS pneumonia: A prospective study. Lancet 361:1767-1772;2003.

14 Peiris JS, Lai ST, Poon LL, Guan Y, Yam LY, Lim W, Nicholls J, Yee WK, Yan WW, Cheung MT, et al. Coronavirus as a possible cause of severe acute respiratory syndrome. Lancet 361 : 1319-325;2003.

15 Rota PA, Oberste MS, Monroe SS, Nix WA, Campagnoli R, Icenogle JP, Penaranda S, Bankamp B, Maher $\mathrm{K}$, Chen MH, et al. Characterization of a novel coronavirus associated with severe acute respiratory syndrome. Science 300:1394-1399;2003.

16 Twu SJ, Chen TJ, Chen CJ, Olsen SJ, Lee LT, Fisk T, Hsu KH, Chang SC, Chen KT, Chiang $\mathrm{IH}_{\text {, et al. Control measures for severe Acute }}$ respiratory syndrome (SARS) in Taiwan. Emerg Infect Dis 9:718--720;2003.

17 Use of laboratory methods for SARS diagnosis, WHO 2003 [Accessed July 2, 2003]. Available from: URL: http://www.who.int/csr/sars/labmethods/en/print.html.

18 van Ginkel FW, Nguyen HH, McGhee JR. Vaccines for mucosal immunity to combat emerging infectious diseases. Emerg Infect Dis 6:123-132;2000 